\title{
PENGUNGKAPAN NILAI ANTI KORUPSI DAN PERAN KOMUNIKASI DALAM BUKU AJAR PENDIDIKAN AGAMA ISLAM DAN BUDI PEKERTI
}

\author{
Muhtadin \\ Universitas Prof. Dr. Moestopo (Beragama), Jakarta - Indonesia \\ muhtadin@dsn.moestopo.ac.id
}

\begin{abstract}
The background of this research is an effort to participate in education in eradicating corrupt behavior. In this effort, it is necessary to inculcate anti-corruption values that are integrated into existing subjects, so that they are not burdensome to emerge new subjects. Furthermore, to provide this education, an effective learning process is needed by using the right communication process so that the cultivation of anti-corruption values can be implemented optimally. This study aims to reveal the anti-corruption values contained in Islamic Education textbooks and then provide an overview of how to build effective communication to be used in learning. This research is a library research with student textbooks as the object of study. The results showed: the values of anti-corruption education contained in the textbook of Islamic Religious Education and Character are the values of honesty, caring, independence, discipline, responsibility, hard work, simplicity, courage, and justice. Effective communication occurs when paying attention to at least five things: clarity of material, accuracy of language use, material context, communication flow, and the environmental culture of students.
\end{abstract}

Keywords: Effective Communication, Anti-Corruption Values, Islamic Education.

\begin{abstract}
Abstrak
Latar belakang penelitian ini adalah upaya peran serta pendidikan dalam memberantas perilaku korupsi. Dalam upaya tersebut, perlu adanya penanaman nilai anti korupsi yang diintegrasikan dalam mata pelajaran yang sudah ada, sehingga tidak membebani untuk dimunculkan mata pelajaran baru. Selanjutnya, untuk memberikan pendidikan tersebut diperlukan suatu pembelajaran yang efektif dengan menggunakan proses komunikasi yang tepat sehingga penanaman nilai anti korupsi tersebut dapat dilaksanakan dengan maksimal. Penelitian ini bertujuan untuk mengungkap nilai-nilai anti korupsi yang terkandung dalam buku ajar PAI dan kemudian memberikan gambaran tentang bagaimana membangun komunikasi yang efektif untuk dapat digunakan dalam pembelajaran. Penelitian ini merupakan penelitian pustaka dengan buku ajar siswa sebagai objek kajiannya. Hasil penelitian menunjukkan: nilai-nilai pendidikan anti korupsi yang terdapat dalam buku ajar Pendidikan Agama Islam dan Budi Pekerti adalah nilai kejujuran, kepedulian, kemandirian, disiplin, tanggung jawab, kerja keras, kesederhanaan, keberanian, dan keadilan. Komunikasi yang efektif terjadi apabila memperhatikan sedikitnya lima hal: kejelasan materi, ketepatan penggunaan bahasa, konteks materi, alur komunikasi, dan budaya lingkungan peserta didik.
\end{abstract}

Kata Kunci: Komunikasi Efektif, Nilai Anti Korupsi, Pendidikan Agama Islam.

\section{PENDAHULUAN}

Sebagai mahkluk sosial, manusia tak lepas dari proses berkomunikasi dengan manusia yang lain. Pertukaran informasi terjadi dalam proses komunikasi, baik berisi tentang berita, peristiwa, maupun hal lain seperti nilainilai dalam bidang pendidikan. Pendidikan sendiri juga memerlukan komunikasi yang baik guna terciptanya pemberian informasi terhadap peserta didik yang dapat merubah perilaku mereka menjadi manusia yang lebih baik.

Pendidikan di Indonesia selalu menjadi perhatian banyak orang, tidak hanya dari pemegang kebijakan tetapi juga dari pelaksana kebijakan yakni guru dan peserta didik. Guru atau pendidik dituntut untuk bisa memiliki kemampuan berkomunikasi yang baik terhadap peserta didiknya supaya tercipta proses 
pembelajaran yang bermutu. Peserta didik juga dituntut untuk mampu menangkap informasi dari sebuah proses komunikasi yang terjadi didalam kelas. Jika kedua hal tersebut terlaksana dengan baik, maka proses pembelajaran akan menghasilkan perubahan yang berarti. Beberapa hal penting yang perlu diperhatikan saat proses pertukaran informasi untuk komunikasi dalam pembelajaran, diantaranya: isi sebagai outcome, tingkat intelegensi dan pengalaman siswa, keaktifan siswa dalam proses pembelajaran, kemajuan dan umpan balik dari siswa, dan kesempatan siswa untuk berlatih (Wisman, 2017:647). Selain hal tersebut, metode komunikasi yang dipakai oleh guru juga menentukan tingkat efektifitas komunikasi dalam suatu pembelajaran.

Persoalan yang harus dihadapi oleh dunia pendidikan begitu kompleks, tak terkecuali persoalan korupsi yang semakin memperihatinkan. Korupsi telah berkembang sedemikian pesatnya sehingga dianggap sebagai kejahatan luar biasa. Kejahatan korupsi dianggap sebagai kejahatan yang sangat merusak karena merugikan banyak orang. Kejahatan ini tidak hanya masuk pada kebijakan ekonomi, namun juga pada politik, kebijakan publik, kesejahteraan sosial, dan juga pada kebijakan pembangunan nasional. Dengan dasar tersebut, maka PBB mengategorikan tentang tindak pidana korupsi ini sebagai sebuah permasalahan global (Rosikah, 2016:1).

Pelaku korupsi sebagian besar merupakan individu yang berpendidikan dengan jabatan yang tinggi. Penyebab dari korupsi salah satunya adalah karena sifat tamak yang ada dalam diri manusia, berapapun tingginya penghasilan yang dihasilkan apabila ada kesempatan maka akan melakukan korupsi juga (BPKP, 1999). Syamsudin, (2011) menjelaskan salah satu penyebab dari korupsi adalah lemahnya pendidikan agama, moral, dan etika. Dari beberapa penyebab korupsi tersebut, menunjukkan bahwa manusia yang berpendidikan tinggi belum tentu terhindar dari perilaku korupsi jika tidak memiliki mental dan moral yang baik dalam dirinya.
Dalam kaitanya dengan upaya untuk melawan korupsi ini, dunia pendidikan sudah seharusnya ikut serta dalam upaya memberantasnya. Pendidikan merupakan salah satu elemen yang diharapkan mampu memberikan pendidikan nilai, moral, maupun pengetahuan yang mempengaruhi sikap dan juga perilaku seseorang dalam kehidupan masyarakatnya. Ki Hajar Dewantara memaknai pendidikan sebagai usaha kebudayaan yang bermaksud memberi bimbingan dalam hidup tumbuhnya jiwa raga anak agar dalam kodrat pribadinya serta pengaruh lingkungannya, mereka memperoleh kemajuan lahir batin menuju ke arah adab kemanusiaan (Mukodi, 2017:116). Berangkat dari makna pendidikan tersebut, diharapkan nantinya dengan pendidikan dapat memberikan kontribusi yang besar untuk perkembangan jiwa raga peserta didik guna memperoleh pengetahuan secara khusus dan secara umum untuk kemajuan peradaban manusia.

Salah satu unsur yang berperan penting dalam pendidikan ataupun pembelajaran adalah sumber belajar itu sendiri atau buku ajar yang digunakan. Buku ajar dituntut untuk dapat memberikan pendidikan yang baik dan mudah untuk digunakan. Dengan buku ajar tersebut peserta didik melalui pendampingan dari guru dapat melaksanakan proses pembelajaran untuk memperoleh pendidikan disetiap jam pembelajaran. Sehingga, dengan adanya buku ajar tersebut dapat digunakan sebagai salah satu jalan untuk bisa memberikan pendidikan yang baik dalam upaya memperbaiki karakter peserta didik seperti pendidikan anti korupsi.

Mata pelajaran yang sangat dekat dengan penanaman nilai-nilai maupun karakter peserta didik salah satunya adalah Pendidikan Agama Islam dan Budi Pekerti. Pendidikan Agama Islam sendiri diartikan sebagai pendidikan yang memberikan pengetahuan dan keterampilan, serta membentuk sikap kepribadian peserta didik dalam mengamalkan ajaran agama Islam (Kemendikbud RI, 2014:34). Sehingga nantinya dengan mata pelajaran Pendidikan Agama Islam dan Budi Pekerti ini, peserta didik mendapatkan pendidikan 
berkaitan dengan agama Islam dan juga memiliki kepribadian yang baik dalam kegiatan bermasyarakatnya tak terkecuali kaitannya dengan niai-nilai anti korupsi.

Selain karena mata pelajaran Pendidikan Agama Islam dan Budi Pekerti merupakan mata pelajaran yang dekat dengan penanaman nilai, hal yang menarik lainnya adalah pada setiap bab yang diajarkan dalam materi Pendidikan Agama Islam dan Budi Pekerti terdapat sikap dan nilai yang harus diteladani oleh peserta didik dan bersinggungan dengan nilai-nilai yang ada dalam pendidikan anti korupsi. Dengan alasan tersebut, seharusnya pendidikan anti korupsi dapat diajarkan sekaligus melalui pembelajaran yang ada dalam Pendidikan Agama Islam dan Budi Pekerti.

Penelitian ini dilakukan atas dasar problematika yang sedang terjadi pada era saat ini. Frimayanti, (2017:86) menjelaskan bahwa pendidikan anti korupsi didasarkan pada pemberantasan korupsi yang dilakukan secara integratif dan simultan yang berjalan beriringan dengan tindakan represif para koruptor. Dengan dasar tersebut seharusnya Pendidikan Agama Islam melakukan inovasi pembelajaran yang bernafaskan nilai anti korupsi sehingga dapat ikut berperan dalam hal pencegahan tindakan korupsi baik melalui bahan ajar yang digunakan maupun dalam praktik pembelajarannya. Namun sayangnya, kebanyakan pendidik lebih terfokus pada tuntutan kurikulum yang baku dan kurang berani untuk melakukan inovasiinovasi tersebut dalam pembelajarannya.

Selain memperhatikan bahan ajar yang digunakan, dalam upaya untuk memberikan pemahaman yang baik tentang materi pembelajaran terhadap peserta didik, juga harus memperhatikan teknik penyampaian informasi atau komunikasi yang tepat dan juga efektif. Teknik komunikasi sendiri diartikan sebagai cara seseorang dalam menyampaikan pesan, gagasan pemikiran, ide atau yang lainnya untuk dapat lebih mudah dipahami oleh orang lain (Nasor, 2014:152). Oleh karenanya, penyampaian pesan dalam pembelajaran didalam kelas penting untuk diperhatikan guna menunjang pembelajaran yang baik. Sehingga dalam pembahasan ini, guru dalam menyampaikan materi disarankan untuk memperhatikan teknik komunikasinya supaya materi yang diajarkan dapat dipahami oleh peserta didik.

Penelitian ini dilakukan dengan tujuan untuk mengungkap nilai-nilai anti korupsi yang ada didalam buku ajar Pendidikan Agama Islam dan Budi Pekerti untuk kemudian memberikan gambaran bagaimana komunikasi yang efektif dalam pembelajaran yang didalamnya disisipkan nilai anti korupsi. Dengan hal tersebut diharapkan nantinya tercipta komunikasi yang efektif didalam pembelajaran dan menghasilkan pembelajaran yang bermutu, pada akhirnya dunia pendidikan ikut andil dalam usaha melakukan perlawanan terhadap korupsi.

Secara etimologi, komunikasi berasal dari bahasa latin communication yang berarti pemberitahuan, memberi bahagian, pertukaran dimana si pembicara mengharapkan pertimbangan dari pendengarnya. Kata kerja dari communication adalah communicara yang berarti bermusyawarah, berunding dan berdialog. Jadi komunikasi dapat berlangsung apabila orang-orang yang terlibat memiliki kesamaan makna mengenai suatu hal yang sedang dikomunikasikan (Onong Uchajana Effendy, 2004:3).

Kemampuan komunikasi adalah suatu kemampuan yang dimiliki untuk menggunakan proses komunikasi yang tepat dan juga efisien (Onong Uchajana Effendy, 2005:9). Adapun definisi komunikasi secara istilah, James A.F. Stones menyebutkan bahwa komunikasi adalah proses dimana seseorang berusaha untuk memberikan pengertian dengan cara pemindahan pesan, dan John R. Schemerhorn menyatakan bahwa komunikasi dapat diartikan sebagai proses antar pribadi dalam mengirim dan menerima simbol yang berarti bagi kepentingan mereka (Onong Uchajana Effendy, 2004:4-5).

Suatu komunikasi yang efektif akan terjadi apabila makna pesan yang dipersepsikan penerima sama dengan maksud dan bayangan 
pengirim. Namun, perlu diketahui bahwa penyampaian pesan di antara pelaku komunikasi sangat dipengaruhi latar belakang mereka masing-masing, bukan sekedar dari kata-kata yang terkandung dalam pesan tersebut (Mulyana, 2011) Sedikitnya terdapat lima aspek yang perlu dipahami dalam membangun komunikasi yang efektif, yaitu : a) Kejelasan, bahwa dalam komunikasi harus menggunakan bahasa dan mengemas informasi secara jelas, sehingga mudah diterima dan dipahami oleh komunikan; b) Ketepatan, ketepatan atau akurasi ini menyangkut penggunaan bahasa yang benar dan kebenaran informasi yang disampaikan; c) Konteks, maksudnya adalah bahwa bahasa dan informasi yang disampaikan harus sesuai dengan keadaan dan lingkungan di mana komunikasi itu terjadi; d) Alur, bahasa dan informasi yang akan disajikan harus disusun dengan alur atau sistematika yang jelas, sehingga pihak yang menerima informasi cepat tanggap; e) Budaya, dalam berkomunikasi harus menyesuaikan dengan budaya orang yang diajak komunikasi, baik dalam bahasa verbal maupun non verbal (Nisa, 2016:51).

Korupsi Secara harfiah diartikan sebagai kebusukan, keburukan, kebejadan, ketidak jujuran, dapat disuap, dan tidak bermoral. Dan dalam Kamus Besar Bahasa Indonesia, korupsi diartikan sebagai penyelewengan atau penyalahgunaan uang negara (baik perusahaan atau lain sebagainya) untuk keuntungan pribadi maupun orang lain (Mukodi, 2017:10). Dari hal ini dapat dimengerti bahwa korupsi merupakan sebuah tindakan yang menyalahi amanah dari wujud tidak bermoralnya seseorang dan perbuatan tersebut merugikan satu pihak dengan menguntungkan pihak pribadi maupun orang lain.

Tindakan korupsi telah lama ada terutama sejak manusia pertama kali mengenal tata kelola administrasi dan kebanyakan kasus korupsi yang dipublikasikan lewat media, sering kali tidak lepas dari kekuasaan, birokrasi atau pun pemerintaan. Korupsi sering juga dikaitkan pemaknaannya dengan politik, kepentingan serta idialisme tak berpendidikan, namun lebih tepat dikategorikan sebagai tindakan yang melanggar hukum.

Sebagai tindakan melanggar hukum, Korupsi adalah sesuatu tindakan yang busuk, jahat, dan merusak, berdasarkan kenyataan tersebut perbuatan korupsi menyangkut: sesuatu yang bersifat amoral, sifat dan keadaan yang busuk, menyangkut jabatan instansi atau aparatur pe-meritah, penyelewengan kekuasaan dalam jabatan karena pemberian, menyangkut factor ekonomi dan politik dan penempatan keluarga atau golongan ke dalam kedinasan di bawah kekuasaan jabatan (Kemendikbud RI, 2011). Kondisi tersebut terjadi dan sudah sangat mengkhawatirkan dan berdampak buruk luar biasa pada hamper seluruh sendi kehidupan. Karena korupsi telah menghancurkan sistem perekonomian, sistem demokrasi, sistem politik, sistem hukum, sistem pemerintahan dan tatanan sosial kemasyarakatan di negeri ini. Di lain pihak walau pun pemberantasan korupsi mengalami peningkatan hasil laporan Transparency International Skor CPI Indonesia ditahun 2016 mencapai 36 poin dibandingkan tahun 2014 mencapai 34 poin (Kompas, 2016 dalam Lu'mu Taris, 2016)) namun upaya pemberantasan korupsi yang telah dilakukan selama ini belum menunjukkan hasil yang mak-simal karena Indonesia masih berada pada peringkat 88 negara korupsi dibawah Singapura, Malaysia atau dari jumlah 168 negara yang dihitung oleh Transparency International (Tempo, 2016 dalam Lu'mu Taris, 2016)

Hal yang dapat diupayakan sebagai bekal utama untuk mencegah terjadinya korupsi adalah mengembangan sikap, moral, dan kepribadian peserta didik sejak dini dan untuk mengembangkan hal tersebut dibutuhkan waktu yang tidak singkat karena pengembangan karak-ter dan watak melalui pembentukan sikap, moral serta kepribadian seseorang berasal dari proses panjang dan berkelanjutan dengan pembiasaan-pembiasaan yang sering dilakukan. Pendidikan anti korupsi perlu diterapkan di sekolah-sekolah karena pada masa ini adalah masa yang paling penting 
dalam menanamkan sikap, moral dan kepribadian yang positif dan tentunya menanamkan sikap anti korupsi.

Tujuan pendidikan menurut UndangUndang Sisdiknas Tahun 2003 yaitu usaha sadar dan terencana untuk mewujudkan suasana belajar dan proses pembelajaran agar peserta didik secara aktif mengembangkan potensi dirinya untuk memiliki kekuatan spiritual keagamaan, pengendalian diri, kepribadian, kecerdasan, akhlak mulia, serta keterampilan yang diperlukan dirinya, masyarakat, bangsa, dan negara (Depdiknas, 2003). Tujuan dapat tercapai dengan menerapkan model pembelajaran yang tepat khususnya dalam mengatasi korupsi, yang tentunya dimulai pada usia dini agar peserta didik sebagai generasi bangsa dapat menyiapkan diri untuk mengembangkan diri tanpa ada sikap dan prilaku korupsi tetapi lebih kepada nilai nilai kejujuran. Kegiatan pembelajaran dapat menanamkan nilai nilai kejujuran jika metode yang diberikan tepat, khususnya dalam mewujudkan tujuan pendidikan.

Pendidikan anti korupsi secara internal sangatlah dipengaruhi oleh nilai-nilai dari anti korupsi yang tertanam dalam diri seseorang. Terdapat sembilan nilai anti korupsi yang dapat dipahami dan diamalkan, pertama tentang kejujuran, kedua berkaitan dengan kepedulian, ketiga kemandirian, keempat kedisiplinan, kelima tanggung jawab, keenam kerja keras, ketuju kesederhanaan, kedelapan tentang keberanian, dan terakhir adalah berkaitan dengan keadilan. Nilai-nilai Anti Korupsi tersebut dapat dijabarkan sebagai berikut:

Nilai Kejujuran. Dalam Kamus Besar Bahasa Indonesia, jujur diartikan sebagai lurus hati, tidak bohong, berkata apa adanya, tidak curang dengan mengikuti aturan yang berlaku, tulus, dan ikhlas. Prinsip kejujuran harus dapat dipegang teguh oleh setiap peserta didik. Nilai kejujuran peserta didik dapat dilakukan dalam bentuk tidak melakukan kecurangan akademik seperti mencontek maupun memalsukan nilai;

Nilai Kepedulian. Nilai kepedulian dapat dilakukan dalam wujud mengindahkan seluruh peraturan yang berlaku dalam lingkungan sekolah bagi warga sekolah khususnya peserta didik. Dapat pula diwujudkan dengan berusaha ikut memantau jalanya proses pembelajaran, sistem pengelolaan sumber daya sekolah, dan juga memantau infrastruruktur dilingkungan sekolah;

Nilai Kemandirian. Dapat diartikan sebagai proses mendewasakan diri, yaitu dengan tidak bergantung pada orang lain untuk menyelesaikan tugas dan juga tanggung jawabnya. Hal ini penting untuk kedepanya supaya peserta didik mampu mengatur dirinya secara mandiri. Dengan kemandirian tersebut, peserta didik dituntut mengerjakan semua tanggung jawabnya dengan usaha dirinya sendiri bukan bergantung pada orang lain;

Nilai Kedisiplinan. Disiplin pada dasarnya merupakan kontrol diri dalam mematuhi aturan baik yang dibuat oleh diri sendiri maupun diluar diri. Dalam perspektif umum disiplin adalah perilaku sosial yang bertanggung jawab dan fungsi kemandirian yang optimal dalam suatu relasi sosial yang berkembang atas dasar kemampuan mengelola, mengendalikan, memotivasi, maupun independensi diri;

Nilai Tanggung Jawab. Tanggung jawab adalah menerima segala sesuatu dari sebuah perbuatan yang salah, baik itu disengaja maupun tidak disengaja. Penerapan nilai ini antara lain dapat diwujudkan dalam bentuk belajar dengan sungguh-sungguh, lulus tepat waktu dengan nilai terbaik, juga menjaga amanah dan kepercayaan yang diberikan;

Nilai Kerja Keras. Kerja keras didasarkan atas kemauan yang tinggi. Kemauan untuk mengantarkan pada setiap individu mempunyai tekat yang tinggi, tekun dalam bekerja dan tujuan yang jelas dalam bertindak. Misalnya dalam melakukan sesuatu menghargai proses bukan hasil semata dan tidak melakukan jalan pintas;

Nilai Kesederhanaan. Dengan gaya hidup sederhana, peserta didik dibiasakan untuk tidak boros, hidup sesuai dengan kebutuhan, sesuai dengan kondisi ekonomi orang tua. Hidup sederhana menjauhkan pada 
bentuk kecemburuan sosial yang tak jarang berujung pada sebuah tindakan melawan hukum;

Nilai Keberanian. Berani menyampaikan pendapat adalah modal awal untuk mencegah terjadinya korupsi. Sikap berani akan semakin kuat jika diimbangi dengan keyakinan yang kuat dalam dirinya. Pengetahuan yang mendalam menimbulkan perasaan percaya diri. Penguasaan terhadap permasalahan yang sedang dihadapi menjadi faktor yang lain untuk menyampaikan pendapatnya tanpa ragu;

Nilai Keadilan. Keadilan diartikan sebagai pemberian hak secara seimbang dengan kewajiban, atau memberikan sesuatu sesuai dengan kebutuhannya. Nilai keadilan dapat dikembangkan pada peserta didik dengan melalui bentuk memberikan saran perbaikan dan semangat pada temannya yang kurang berprestasi, tidak memilih teman bergaul berdasarkan suku, agama, ras, dan golongan tertentu (Mukodi, 2017:83-85).

Sikap jujur sangat penting untuk ditanamkan pada semua orang guna melatih mereka untuk selalu berperilaku jujur dalam kehidupanya kelak. Kejujuran akan menjadi modal penting bagi individu memiliki sikap anti korupsi. Hal ini disebabkan karena dengan kejujuran yang dimilikinya, seseorang tidak akan melakukan tindakan korupsi karena akan bertentangan dengan prinsip dasar dari nilai kejujuran.

Sikap tanggung jawab akan membentuk pribadi yang bersahaja. Jika seseorang mampu melaksanakan tanggung jawabnya dalam segala hal, maka akan mampu menjaga segala amanah yang diterimanya. Dengan hal tersebut, individu akan terhindar dari sikap-sikap negatif seperti korupsi, karena korupsi merupakan cerminan dari seseorang yang tidak memiliki nilai tanggung jawab.

Undang-undang Nomor 31 tahun 1999 juncto UU no 20 tahun 2001 tentang Pemberantasam Tindak Pidana Korupsi menyebutkan dengan jelas jenis-jenis tindak pidana korupsi. Tindak pidana korupsi dibagi menjadi tujuh jenis, yaitu terkait dengan kerugian keuangan negara, suap-menyuap, penggelapan dalam jabatan, pemerasan, perbuatan curang, benturan kepentingan dalam pengadaan, dan gratifikasi (Rosikah, 2016:17). Hal ini memberikan gambaran bahwa bentuk korupsi sangat beragam adanya dan jenis-jenis korupsi ini hendaknya dikenalkan kepada peserta didik untuk mereka bisa menghindari dan menjauhinya sebisa mungkin.

Jika melihat dalam sejarah Islam, korupsi pada masa Nabi Muhammad saw pernah terjadi, diantaranya kisah yang diriwayatkan oleh Al Bukhori:

Dari Abdullah ibn Amr ra, ia berkata: "ada seseorang yang bernama Karkirah yaitu pembawa barang-barang Nabi, ia mati dalam peperangan lalu Nabi mengatakan: "ia masuk neraka". Kemudian para sahabat memeriksanya dan menemukan sehelai pakaian yang ia korup dari ghonimah". (HR. Al Bukhori)

Karkirah merupakan seseorang yang suka membawakan barang Nabi ketika peperangan terjadi. Ketika Karkirah wafat, Nabi kemudian memfonisnya masuk neraka, bahkan Nabi enggan untuk mensholatinya. Hal ini didasarkan pada perilakunya yang telah menyembunyikan sehelai pakaian ghonimah yang belum dibagi bagian-bagiannya (Birahmat, 2018:69).

Didalam Al Qur'an memang tidak disebutkna secara jelas mengenai istilah korupsi, namun ada beberapa ayat yang menyinggung hal tersebut salah satunya Q.S Ali Imran ayat 161, yang artinya: "tidak mungkin seseorang Nabi berkhianat dalam urusan harta rampasan perang. Barangsiapa yang berkhianat dalam urusan rampasan itu, maka pada hari kiamat ia akan datang membawa apa yang dikhianatkan, kemudian tiap-tiap diri akan diberi pembalasan tentang apa yang ia kerjakan dengan (pembalasan) setimpal, sedang mereka tidak dianiaya."

Penjelasan ayat tersebut adalah dalam ayat ini ada istilah ghulul yang berarti penghianatan. Menurut Al Maraghi menjelaskan bahwa kata ghulul dalam ayat ini bermakna mengambil sesuatu dengan 
sembunyi-sembunyi, misalnya mencuri sesuatu. Rasulullah sendiri memperluas makna ghulul menjadi dua bentuk, yakni Komisi dan Hadiah. Komisi merupakan tindakan mengambil sesuatu penghasilan di luar gaji yang telah diberikan. Dalam hal ini Nabi bersadba: "barangsiapa yang kami angkat menjadi pegawai pada suatu pekerjaan kemudian kami tetapkan gaji tertentu untuknya, maka apa yang dipungutnya sesudah itu adalah kecurangan (korupsi). (HR. Abu Daud). Sedangkan Hadiah diartikan sebagai pemberian yang didapatkan seseorang karena jabatan yang melekat pada dirinya. Dalam hal ini juga, Nabi bersabda: "Hadiah yang diterima para pejabat adalah korupsi (ghulu)”. (HR. Ahmad) (Birahmat, 2018:70).

Dengan penjelasan tersebut, patut untuk dijadikan sebagai renungan dan dasar tindakan yang kuat untuk dilakukannya suatu usaha menghilangkan prilaku korupsi. Komisi maupun Hadiah sejatinya merupakan hal yang sudah lumrah dijumpai dalam kehidupan sehari-hari. Namun jika kedua hal tersebut dilakukan oleh individu yang terikat dalam suatu jabatan tertentu, maka komisi dan hadiah bisa menjadi hal yang menyeret orang tersebut kedalam tindak kejahatan korupsi. Maka sangat penting untuk dilakukan pendidikan yang memberikan pengetahuan tentang bagaimana pencegahan-pencegahan yang bisa dilakukan supaya tidak terjebak dalam lingkaran korupsi.

Pendidikan Agama Islam dan Budi Pekerti adalah pendidikan yang memberikan pengetahuan dan keterampilan, serta membentuk sikap kepribadian peserta didik dalam mengamalkan ajaran agama Islam (Kemendikbud RI, 2014:3-4). Pendidikan Islam adalah suatu sistem yang lengkap dengan sistematika yang epistemik yang terdiri dari teori, praktik, metode, nilai, dan pengorganisasian yang saling berhubungan melalui kerja sama yang harmonis dalam konsepsi Islam tentang Allah, alam semesta, manusia, dan masyarakat (Minarti, 2013:28).

Pendidikan agama Islam adalah pendidikan dengan melalui ajaran-ajaran agama Islam, yaitu berupa bimbingan dan asuhan terhadap anak didik agar nantinya setelah selesai dari pendidikan ia dapat memahami, menghayati, dan mengamalkan ajaran-ajaran agama Islam yang telah diyakininya secara menyeluruh, serta menjadikan ajaran agama Islam itu sebagai suatu pandangan hidupnya demi keselamatan dan kesejahteraan hidup didunia maupun diakhirat kelak (Darajat, 1998:28).

Berdasarkan pengertian tersebut dapat dimengerti bahwa pendidikan agama Islam itu adalah pendidikan yang memberikan pengetahuan dan keterampilan, serta membentuk sikap kepribadian peserta didik dalam mengamalkan ajaran agama Islam dan menjadikan ajaran agama Islam itu sebagai suatu pedoman dalam pandangan hidupnya.

Buku ajar merupakan salah satu sumber dan media yang dapat digunakan dalam proses pembelajaran. Buku sebagai bahan atau sebagai media belajar memiliki banyak keunggulan, diantaranya adalah dapat digunakan secara aktif untuk membantu proses belajar peserta didik secara mandiri, buku ajar lebih mudah dibawa, buku dapat memuat bidang pengetahuan yang lebih luas dan dapat mengikuti perkembangan zaman (Arif, 1997:39).

Buku ajar ataupun buku pelajaran sendiri merupakan sarana untuk memberikan pengetahuan kepada peserta didik, ini berarti bahwa buku pelajaran digunakan di sekolah baik digunakan oleh guru sebagai pendidik maupun siswa sendiri sebagai peserta didik. Buku ajarpun harus sesuai dengan tujuan yang diinginkan oleh lembaga pendidikan, yang mengacu dan disesuaikan dengan kebutuhan yang ada, dan juga disesuaikan dengan masalah-masalah yang ingin dipecahkan oleh masyarakat secara luas.

Buku ajar yang masuk kategori baik harus memiliki fungsi pendidikan bagi para pembacanya. Adapun kriteria buku ajar yang bersifat mendidik adalah yang pertama memiliki informasi aktual, kedua menunjukan tingkat relevansi yang tinggi terhadap tuntunan kurikulum, ketiga adanya keseimbangan antar bagian secara proporsional, dan keempat 
mampu tampil dengan bahasa yang dapat dimengerti oleh pembacanya (Suyanto, 2000:124-125).

Dapat disimpulkan pula bahwa buku ajar yang baik adalah buku ajar yang dapat menjadi sumber bagi peserta didik untuk mampu merangsang proses berpikirnya guna mengetahui informasi yang aktual sehingga dalam kehidupanya dapat menyelesaikan persoalan-persoalan yang ada dengan kemampuan dan pengetahuan yang telah dimilikinya.

Sejauh penelusuran peneliti terhadap berbagai sumber pustaka, belum ditemukan hasil penelitian yang fokus pembahasannya tentang Komunikasi Efektif Pendidikan Anti Korupsi dalam PAI dan Implementasinya dalam Pembeljaaran. Berikut ini akan diuraikan mengenai beberapa kajian pustaka yang relevan dengan penelitian yang akan dilakukan oleh penulis.

Penelitian yang dilakukan oleh Frimayanti, (2017) dengan fokus penelitian pada konsep pendidikan anti korupsi yang ditekankan pada peserta didik sejak dini dengan membiasakan hidup anti korupsi, melalui pengenalan gaya hidup anti korupsi, akibat korupsi, dan penanaman nilai-nilai ajaran agama ke dalam diri peserta didik. Kemudian implikasi dari pendidikan anti korupsi dalam pendidikan agama Islam adalah kurikulumnya harus dikaitkan dengan seluruh mata pelajaran pada nilai-nilai anti korupsi.

Penelitian yang dilakukan oleh Fadhil, (2019), Fokus penelitiannya adalah pada usaha menginternalisasikan nilai-nilai anti korupsi dalam PAI. Hasil penelitian ini menyimpulkan bahwa model PAI saat ini masih sebatas pada konsep yang dogmatis, sehingga masih terjebak pada bentuk struktural. PAI belum mengeksplorasi secara fungsional kemampuan dirinya dalam menginternalisasikan nilai-nilai anti korupsi. Oleh karena itu, sudah saatnya PAI melakukan transformasi model pembelajaran bagi peserta didik yang tidak hanya membangun moralitas individual namun juga moralitas publik.
Penelitian yang dilakukan oleh Nisa, (2016) dengan fokus penelitian pada bagaimana membangun komunikasi yang efektif dalam upaya pendidikan karakter. Komunikasi menjadi sistem dalam proses pendidikan karakter. Komunikasi yang efektif memiliki ketentuan, syarat, prinsip dan strategi yang kesemuanya terletak pada kualitas pendidik dalam menempatkan fungsi dan tanggung jawabnya sebagai seorang pendidik.

Penelitian yang dilakukan oleh Wisman, (2017) dengan fokus penelitian pada menggali metode yang tepat dalam komunikasi pendidikan, strategi untuk meningkatkan efektifitas komunikasi dalam pendidikan, dan untuk memahami hambatan dalam komunikasi pendidikan. Penelitian ini kemudian menyimpulkan bahwa metode yang tepat dalam komunikasi pendidikan adalah dengan komunikasi secara langsung maupun tak langsung disesuaikan dengan situasi dan kondisi. Strategi untuk meningkatkan efektifitas komunikasi dalam pendidikan adalah dengan mengenali sasaran komunikasi, memilih media komunikasi yang tepat, mengkaji tujuaan pesan, dan memaksimalkan peranan komunikator. Hambatan dalam komunikasi antara lain, hambatan dalam proses, hambatan fisik, semantik dan psikologis.

Penelusuran yang peneliti temukan memang banyak membahas mengenai Komunikasi Efektif dan Pendidikan Anti Korupsi, namun peneliti belum menemukan penelitian yang fokus pada Komuniasi Efektif Pendidikan Anti Korupsi dalam PAI dan Implementasinya dalam Pembelajaran. Hal inilah yang membedakan penelitian yang penulis buat dengan penelitian yang sudah ada sebelumnya.

\section{METODOLOGI PENELITIAN}

Setiap penelitian pasti menggunakan suatu paradigma tertentu yang digunakan sebagai kacamata penelitian. Paradigma oleh Kuhn dipahami sebagai upaya-upaya ilmiah yang diakui secara universal sehingga mampu memahami suatu persoalan dan memberikan 
pemecahan masalahnya bagi suatu komunitas pengguna. Paradigma menyediakan suatu kerangka kerja yang mencakup seperangkat teori, metode dan cara-cara penentuan data pada suatu domain (Umanailo, 2015). Paradigma dipandang sebagai suatu hal yang penting karena kemampuannya membedah realitas empirik dan keluwesannya dalam menyikapi persoalan yang akan dipecahkan. Dengan kata lain, paradigma adalah suatu sudut pandang yang dipakai untuk memahami suatu fenomena secara lebih lengkap. Dalam penelitian ini, penulis menggunakan paradigma Post-Positivisme. Menurut Guba (1990:20) (dalam Ievansyah \& Sadono, 2018) "Postpositivism is best characterized asmodified version of positivism. Having assessed the damage that positivism has occured, postpositivists strunggle to limited that damage as well as to adjust to it. Prediction and control continue to be the aim. Fakta sosial yang dimaksud adalah mencakup bahasa, sistem hukum, politik, maupun pendidikan. Dalam hal ini, paradigma tersebut digunakan untuk mengungkapkan bagaimana pendidikan anti korupsi yang disisipkan dalam pembelajaran PAI dan bagaimana komunikasi efektif bisa dibangun dalam pembelajarannya.

Penelitian ini menggunakan pendekatan kualitatif. Penelitian kualitatif dipengaruhi oleh paradigma naturalistik-interpretatif. Dimana peneliti berusaha mengkonstruksi realitas dan memahami maknanya sehingga penelitian ini sangat memperhatikan proses, peristiwa, dan otensitas. (Cresswell, John W, 1994 dalam Jumal Ahmad, 2018)

Penelitian ini merupakan penelitian library research, yakni hasil penelusuran pustaka digunakan sebagai tumpuan utama keseluruhan penelitian (Zed, 2004:1-2). Kajian pustaka (library research), yaitu studi kepustakaan dari berbagai referensi yang relevan dengan pokok pembahasan. Penelitian kepustakaan digunakan untuk memecahkan problem yang bersifat konseptual-teoritis, baik tentang tokoh pendidikan atau konsep pendidikan tertentu seperti tujuan, metode, dan lingkungan pendidikan. Penelitian ini biasanya menggunakan pendekatan sejarah, filsafat, semiotik, hermeneutika, filologi, dan sastra. Secara sederhana, penelitian pustaka adalah sebuah penelitian yang berusaha menghimpun data penelitian dari khazanah literatur dan menjadikan dunia teks sebagai objek utama analisisnya (Suwadi, 2015:20). Oleh karena itu peneliti mengumpulkan data dan kemudian mengkaji buku-buku ataupun sumber bacaan yang lain yaitu sumber yang memiliki relevansi dengan penelitian ini yaitu tentang nilai nilai Anti Korupsi dalam Buku Ajar Pendidikan Agama Islam Dan Budi Pekerti.

Penelitian ini menggunakan metode pengumpulan data dokumentasi, yaitu mencari data mengenai variabel-variabel yang bersangkutan dengan penelitian ini dari sumber data berupa dokumen tertulis seperti: buku, transkrip, surat kabar, majalah, dan peraturan perundang-undangan(Sugiono, 2009:82).. Data yang terkumpul dari berbagai sumber akan dianalisis dengan menggunakan content analysis secara kualitatif.

Penelitian kualitatif dipengaruhi oleh paradigma naturalistik-interpretatif. Dimana peneliti berusaha mengkonstruksi realitas dan memahami maknanya sehingga penelitian ini sangat memperhatikan proses, peristiwa, dan otensitas. Menggunakan metode analisis isi harus mengamati fenomena komunikasi, dengan merumuskan dengan tepat apa yang diteliti dan semua tindakan harus didasarkan pada tujuan tersebut. Selanjutnya memilih unit analisis yang akan dikaji, memilih objek penelitian yang menjadi sasaran analisis. Apabila objek penelitian berhubungan dengan data-data verbal maka perlu disebutkan tempat, tanggal dan alat komunikasi yang bersangkutan. Namun, kalau objek penelitian berhubungan dengan pesanpesan satu dalam suatu media, perlu dilakukan identifikasi terhadap pesan dan media yang mengantarkan pesan itu.

Teknik ini digunakan untuk menarik kesimpulan melalui usaha untuk menemukan karakteristik pesan dan dilakukan secara obyektif dan sistematis (Moleong, 2002:163). Karakteristik utamanya yaitu dengan 
melakukan penglarifikasian materi simbolis dengan mempertimbangkan bagian-bagian dari materi tekstual yang benar-benar berada dalam kategori skema penelitian. Pernyataan dan tanda dalam teks dipandang sebagai bahan mentah yang harus diolah agar dapat menghasilkan dampak terhadap isi(Tischer, 2009:98).

\section{HASIL DAN PEMBAHASAN}

Berdasarkan analisis yang dilakukan terhadap buku ajar PAI dan Budi Pekerti, terdapat banyak materi pokok dalam buku tersebut yang berkaitan dengan nilai-nilai pendidikan anti korupsi, seperti kejujuran, kepedulian, kemandirian, kedisiplinan, tanggung jawab, kerja keras, kesederhanaan, keberanian, dan terakhir adalah berkaitan dengan keadilan.

Penelitian yang dilakukan oleh Nisa, (2016) dengan fokus penelitian pada bagaimana membangun komunikasi yang efektif dalam upaya pendidikan karakter. Komunikasi menjadi sistem dalam proses pendidikan karakter. Komunikasi yang efektif memiliki ketentuan, syarat, prinsip dan strategi yang kesemuanya terletak pada kualitas pendidik dalam menempatkan fungsi dan tanggung jawabnya sebagai seorang pendidik.

Upaya untuk memberikan pendidikan anti korupsi melalui Pendidikan Agama Islam, maka proses pembelajaran yang dilakukan harus efektif dan berhasil. Dalam usaha untuk memberikan pembelajaran yang efektif, maka harus menggunakan komunikasi yang efektif pula dalam memberikan materi tersebut dalam pembelajaran. Komunikasi efektif tersebut dapat dilakukan dan diimplementasikan sedikitnya dalam lima hal: a) Kejelasan. Dalam proses pembelajaran Pendidikan Agama Islam yang didalamnya disisipkan pendidikan anti korupsi, diharuskan menggunakan bahasa komunikasi yang mudah, dan mengemas informasi pembelajarannya secara rinci mengenai bagaimana keterkaitan antara materi PAI yang sedang diajarkan dengan nilai anti korupsi, sehingga materi yang akan diterima dan dipahami oleh peserta didik akan mudah diterima; b) Ketepatan. Ketepatan konten materi yang akan diberikan kaitanya dengan pendidikan anti korupsi dalam pembelajaran Pendidikan Agama Islam perlu diperhatikan. Guru harus mempersiapkan konten materi apa saja yang akan di sajikan didalam kelas kaitanya dengan penanaman nilai anti korupsi. Selain itu juga bahasa yang digunakan haruslah bahasa yang tepat dan tidak menggunakan bahasa-bahasa yang multitafsir; c) Konteks. Maksudnya adalah bahwa bahasa dan informasi yang disampaikan harus sesuai dengan keadaan dan lingkungan di mana komunikasi itu terjadi. Ketika proses pembelajaran terjadi, maka konteks materi disesuaikan dengan lingkungan pembelajaran. Sebagai contoh, pengemasan materi yang ditujukan untuk peserta didik kelas $\mathrm{X}$ akan berbeda pendekatanya dari segi bahasa maupun konteksnya dengan peserta didik kelas XI, begitu juga konteks materi untuk peserta didik kelas XI akan berbeda dengan peserta didik pada kelas XII; d) Alur. Bahasa dan informasi yang akan disajikan harus disusun dengan alur atau sistematika yang jelas, sehingga pihak yang menerima informasi dapat secara cepat dan tanggap serta antusias. Disinilah peran Rencana Pelaksanaan Pembelajaran (RPP) dalam mengatur susunan pelaksanaan pembelajaran sehingga dalam proses pertukaran informasi mengenai pendidikan anti korupsi dalam pembelajaran Pendidikan Agama Islam didalam kelas, memiliki alur yang jelas dan tidak rancu; e) Budaya. Dalam berkomunikasi harus menyesuaikan dengan budaya individu yang diajak komunikasi, ketika peserta didik memiliki kebiasaan berkomunkasi dengan bahasa verbal maka pembelajaran harus disesuaikan dengan kondisi budaya yang terjadi didalam kelas tersebut, dan ketika peserta didik cenderung lebih bisa menangkap menggunakan bahasa non-verbal maka guru harus bisa menyesuaikannya.

Dengan lima hal tersebut diatas, implementasi pembelajaran Pendidikan Agama Islam yang didalamnya disisipkan nilai anti korupsi dapat berjalan dengan baik. Jika lima langkah komunikasi efektif diatas dilakukan 
dalam pembelajaran, bukan tidak mungkin peserta didik akan tertarik karena komunikasi yang dibangun didasarkan pada kejelasan materi, ketepatan konten, penyesuaian konteks, alur pembelajaran yang teratur dengan menggunakan Rencana Pelaksanaan Pembelajaran (RPP), dan menyesuaikan dengan budaya komunikasi peserta didik dalam pembelajaran sehingga pembelajaran pun akan berjalan secara efektif.

Upaya yang dilakukan diatas, sejalan dengan Penelitian yang dilakukan oleh Wisman, (2017) dengan fokus penelitian pada menggali metode yang tepat dalam komunikasi pendidikan, strategi untuk meningkatkan efektifitas komunikasi dalam pendidikan, dan untuk memahami hambatan dalam komunikasi pendidikan. Penelitian ini kemudian menyimpulkan bahwa metode yang tepat dalam komunikasi pendidikan adalah dengan komunikasi secara langsung maupun tak langsung disesuaikan dengan situasi dan kondisi. Strategi untuk meningkatkan efektifitas komunikasi dalam pendidikan adalah dengan mengenali sasaran komunikasi, memilih media komunikasi yang tepat, mengkaji tujuaan pesan, dan memaksimalkan peranan komunikator.

\section{SIMPULAN}

Temuan yang dapat ditemukan oleh penulis dalam penelitian ini adalah adanya sembilan nilai anti korupsi yang dapat diintegrasikan kedalam pembelajaran Pendidikan Agama Islam dan Budi Pekerti. Sembilan nilai tersebut dapat ditanamkan kedalam diri peserta didik melalui proses pembelajaran Pendidikan Agama Islam sehingga tidak perlu menjadi mata pelajaran tersendiri. Dalam usaha untuk menanamkan sembilan nilai pendidikan anti korupsi tersebut, maka diperlukan komunikasi antar pendidik dan peserta didik yang efektif sehingga terjadi pertukaran informasi yang baik. Sedikitnya ada lima hal yang dapat dijadikan pertimbangan supaya komunikasi dalam proses pembelajaran dapat terlaksana dengan baik, yakni kejelasan materi yang akan diajarkan, ketepatan penggunaan bahasa dalam penyampaiannya, konteks materi, alur komunikasi yang bagus, dan penyesuaian budaya komunikasi pada lingkungan peserta didik.

\section{DAFTAR PUSTAKA}

Arif, Z. (1997). Pedoman Baru Menyusun Bahan Ajar. Gramedia.

Birahmat, B. (2018). Korupsi dalam Perspektif Al Qir'an. Jurnal IAIN Curup, 3(1). http://journal.iaincurup.ac.id/index.php/JF /article/download/457

BPKP. (1999). Strategi Pemberantasan Korupsi Nasional. Pusat Pendidikan dan Pengawasan BPKP.

Darajat, Z. (1998). Ilmu Pendidikan Islam. Bumi Aksara.

Depdiknas. (2003). Undang Undang No 20 Tahun 2003 tentang Sistem Pendidikan Nasional.

Fadhil, M. (2019). Pendidikan Agama Islam, Internalisasi Nilai-Nilai Anti Korupsi dan Pencegahan Tindak Pidana Korupsi. Jurnal JRTIE, 2(1). https://www.researchgate.net/publication/ 330518887_Pendidikan_Anti_Korupsi_D alam_Pendidikan_Agama_Islam

Frimayanti, A. I. (2017). Pendidikan Anti Korupsi Dalam Pendidikan Agama Islam. Jurnal Al Tadzkiyah, 8(1). https://www.researchgate.net/publication/ 330518887_Pendidikan_Anti_Korupsi_D alam_Pendidikan_Agama_Islam

Ievansyah, I., \& Sadono, T. P. (2018). Personal Branding Dalam Komunikasi Selebritis (Studi Kasus Personal Branding Alumni Abang None Jakarta Di Media Sosial "Instagram"). Bricolage: Jurnal Magister Ilmu Komunikasi, 4(02), 149. https://doi.org/10.30813/bricolage.v4i02. 1658

Jumal Ahmad. (2018). Desain Penelitian Analisis Isi (Content Analysis). ResearchGate, June, 1-20. https://doi.org/10.13140/RG.2.2.12201.08 804

Kemendikbud RI. (2011). Pendidikan Anti 
Korupsi Untuk Perguruan Tinggi.

Kemendikbud RI. (2014). peraturan Menteri Pendidikan dan Kebudayaan Nomor 59 Tahun 2014 tentang Kurikulum 2013 Sekolah Menengah Atas/Madrasah Aliyah.

Lu'mu Taris, M. R. (2016). Implementasi Media Pembelajaran Anti Korupsi Berbais Gender Untuk Menanamkan Nilai-Nilai Kejujuran di SD. Jurnal Penelitian Pendidikan INSANI, 19(2).

Minarti, S. (2013). Ilmu Pendidikan Islam: Fakta Teoritis-Filosofis dan AplikatifNormatif. Amzah.

Moleong, L. J. (2002). Metodologi Penelitian Kualitatif. Remaja Rosdakarya.

Mukodi. (2017). Model Penyadaran Anti Korupsi: redesain konseptual dan aplikatif melalui teenager corruption wacth. LPPM Press STKIP PGRI.

Mulyana, D. (2011). Ilmu Komunikasi Sekarang dan Tantangan Masa Depan. Kencana.

Nasor, M. (2014). Teknik Komunikasi Guru dan Siswa dalam Peningkatan Prestasi Siswa. Ijtimaiyya, 7(1). https://media.neliti.com/media/publicatio ns/69422-ID-teknik-komunikasi-gurudan-siswa-dalam-p.pdf

Nisa, H. (2016). Komunikasi yang Efektif dalam Pendidikan Karakter. Jurnal Universum, $\quad$ 10(1). https://jurnal.iainkediri.ac.id/index.php/un iversum

Onong Uchajana Effendy. (2004). Dinamika Komunikasi. Remaja Rosdakarya.

Onong Uchajana Effendy. (2005). Ilmu Komunikasi: Teori dan Praktek. Remaja Rosdakarya.

Rosikah, C. D. (2016). Pendidikan Anti Korupsi: kajian anti korupsi teori dan praktik. Sinar Grafika.

Sugiono. (2009). Memahami Penelitian Kualitatif. Alfabeta.

Suwadi. (2015). Panduan Penulisan Skripsi. Jurusan Pendidikan Agama Islam fakultas Ilmu Tarbiyah dan Keguruan UIN Sunan Kalijaga.

Suyanto. (2000). Refleksi dan Reformasi Pendidikan Di Indonesia Memasuki Milenium III. Adicita Karya Nusa.

Syamsudin, A. (2011). Tindak Pidana Khusus. Sinar Grafika.

Tischer, S. (2009). Metode Analisis Teks dan Wacana (Ghazali (ed.)). Pustaka Pelajar.

Umanailo, M. C. B. (2015). Ilmu Sosial Budaya Dasar (Edition Pertama). https://doi.org/10.17605/OSF.IO/4HPWC

Wisman, Y. (2017). Komunikasi Efektif dalam Dunia Pendidikan. Jurnal Nomosleca, $3(2)$.

http://jurnal.unmer.ac.id/index.php/n/artic le/view/2039

Zed, M. (2004). Metode Penellitian Kepustakaan. Yayasan Obor Indonesia. 